\title{
Optimisation of the allylsilane approach to C-10 deoxo carba analogues of dihydroartemisinin: synthesis and in vitro antimalarial activity of new, metabolically stable $\mathrm{C}-10$ analogues
}

\author{
Paul M. O’Neill, ${ }^{* a}$ Matthew Pugh, ${ }^{a}$ Andrew V. Stachulski, ${ }^{a}$ Stephen A. Ward, ${ }^{c}$ Jill Davies ${ }^{c}$ and \\ B. Kevin Park ${ }^{b}$ \\ ${ }^{a}$ The Robert Robinson Laboratories, University of Liverpool, Liverpool, UK L69 7ZD \\ ${ }^{b}$ Department of Pharmacology and Therapeutics, University of Liverpool, Liverpool, \\ $U K L 693 G E$ \\ ${ }^{c}$ Liverpool School of Tropical Medicine, University of Liverpool, Liverpool, UK L3 5QA
}

Received (in Cambridge, UK) 17th May 2001, Accepted 13th August 2001

First published as an Advance Article on the web 19th September 2001

An optimised protocol has been developed for the coupling of dihydroartemisinin benzoate with a range of aromatic allylsilanes to provide a number of new C-10 deoxo derivatives (11a-11g) in yields ranging from 70 to $94 \%$. These compounds were up to ten times more potent than artemisinin in in vitro tests against the chloroquine resistant $\mathrm{K} 1$ strain of Plasmodium falciparum. Ferrous mediated degradation of these analogues produces as the main product, a dicarbonyl formate 12, which is not seen when the same reaction is carried out with artemisinin or artemether. This finding may indicate that analogues in this class have a subtly different "antimalarial" mechanism of action.

\section{Introduction}

Malaria has a devastating effect throughout the tropics. There are approximately 300 to 500 million clinical cases each year resulting in 1.5 to 2.7 million deaths. Nearly all fatal cases are caused by Plasmodium falciparum. ${ }^{1}$ The problem is compounded by the spread of drug resistant strains of the parasite. As a result traditional alkaloid drugs such as chloroquine $\mathbf{1}$ and quinine are now largely ineffective.

In 1979 it was shown that artemisinin (Qinghaosu) 2, a sesquiterpene 1,2,4-trioxane isolated from the Chinese medicinal herb qinghao (Artemisia апnиа L.), was an effective antimalarial against chloroquine-resistant strains of Plasmodium falciparum. $^{2}$ Artemisinin has been very impressive in preliminary pharmacological testing; however its poor solubility in both oil and water and hydrolytic instability of the lactone function has led scientists to prepare a series of semisynthetic first generation analogues such as artemether (3a $\left.\mathrm{R}=-\mathrm{CH}_{3}\right)$ and arteether $\left(3 \mathbf{b}, \mathrm{R}=-\mathrm{CH}_{2} \mathrm{CH}_{3}\right){ }^{3}$ Both of these derivatives are readily prepared from dihydroartemisinin (DHA, 3c), which in turn is produced by borohydride mediated reduction of the D-ring lactone of $2 .^{4}$ Although $\mathbf{3 a}$ and $\mathbf{3 b}$ are potent antimalarials, poor bioavailability and rapid clearance are observed with these derivatives both in man and in animal models. $^{5}$ This phenomenon is associated with the inherent chemical and metabolic instability of the acetal functionality. One of the main routes of metabolism of artemether in the rat model involves P450 mediated hydroxylation of the C-10 methyl ether function to an unstable hemiacetal that hydrolyses to dihydroartemisinin. ${ }^{6}$ This phase 1 metabolite then undergoes Phase II glucuronidation and is excreted as dihydroartemisinin $\beta$-glucuronide. ${ }^{7}$

The increased stability of non acetal-type analogues (e.g.4) of artemisinin has recently been reported. C-10-Deoxoartemisinins have been shown to be 15-22 times more stable than acetal-type analogues in simulated stomach acid. ${ }^{8}$ Such favourable findings have led several groups to develop synthetic and semisynthetic approaches to C-10-deoxoartemisinin derivatives. Early syntheses tended to be lengthy, using artemisinic acid as starting material. ${ }^{9} \mathrm{Pu}$ and Ziffer ${ }^{10}$ successfully used DHA with allyltrimethylsilane in the presence of boron trifluoride-diethyl
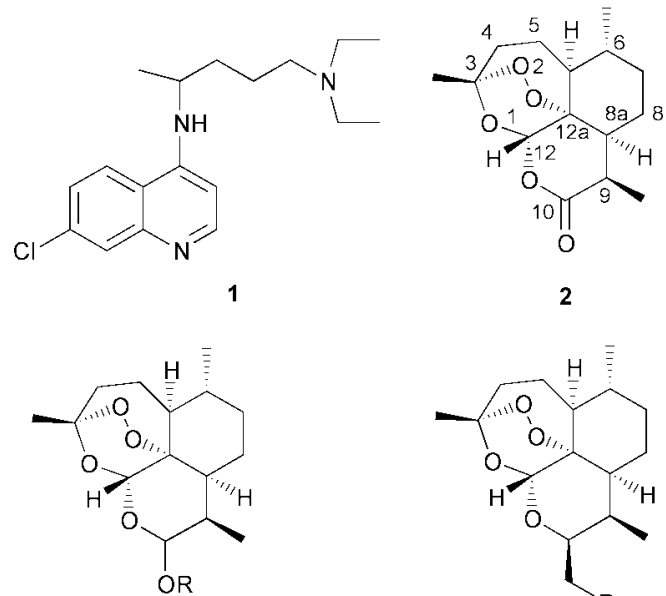

$$
\begin{aligned}
& \text { 3a, } R=M e, \beta \text {-isomer } \\
& \text { 3b, } R=E t, \beta \text {-isomer } \\
& \text { 3c. } R=H, \text { mixture of } \alpha \\
& \text { and } \beta \text { isomers }
\end{aligned}
$$

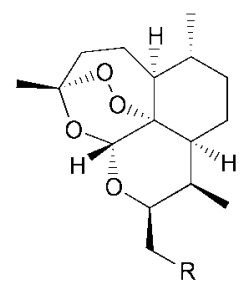

4, R = Alkyl, Ary

ether to synthesise a wide range of these compounds and have more recently shown that dihydroartemisinin acetate can be employed as starting material using silyl enol ethers in the presence of titanium tetrachloride. ${ }^{11}$ Posner and coworkers have reported a two-step conversion of DHA, via an intermediate 10-fluoro derivative, into a series of aromatic and heterocyclic deoxoartemisinin derivatives. ${ }^{12-13}$ Wang et al., via the acid-catalysed reaction of dihydroartemisinin acetate with 2-naphthol, produced two 10-(2-hydroxy-1-naphthyl)deoxoartemisinins. ${ }^{14}$ Previously, we have reported on the synthesis of a range of potent $\mathrm{C}$-10-deoxo carba ether and ester derivatives, some of which were more than fifteen times more potent than the parent drug artemisinin. ${ }^{15}$ In this paper, we report on an optimised approach to C-10 carba analogues which is based on the Lewis acid catalysed reaction of a range of allylsilanes with an anomerically activated C-10 benzoate of dihydroartemisinin. We also report on the potent activity of these new derivatives, which, based on biomimetic Fe(II) chemistry, may be different from the parent drug artemisinin. ${ }^{16}$ 


\section{Results and discussion}

A key intermediate for the preparation of a range of carba analogues of artemisinin, including parasite targeted amine analogues, ${ }^{17}$ water soluble sugar analogues ${ }^{18}$ fluorinated benzyl ethers ${ }^{15}$ and antitumour dimers ${ }^{19}$ is C-10-allyldeoxoartemisinin 4a. The original synthesis of $\mathbf{4 a}$ involves Lewis acid mediated $\left(\mathrm{BF}_{3} \cdot \mathrm{Et}_{2} \mathrm{O}\right)$ reaction of DHA with allyltrimethylsilane as carbon nucleophile. In this reaction, it is proposed that the product is derived by axial attack of allyltrimethylsilane on the intermediate oxonium ion. (Scheme 1).

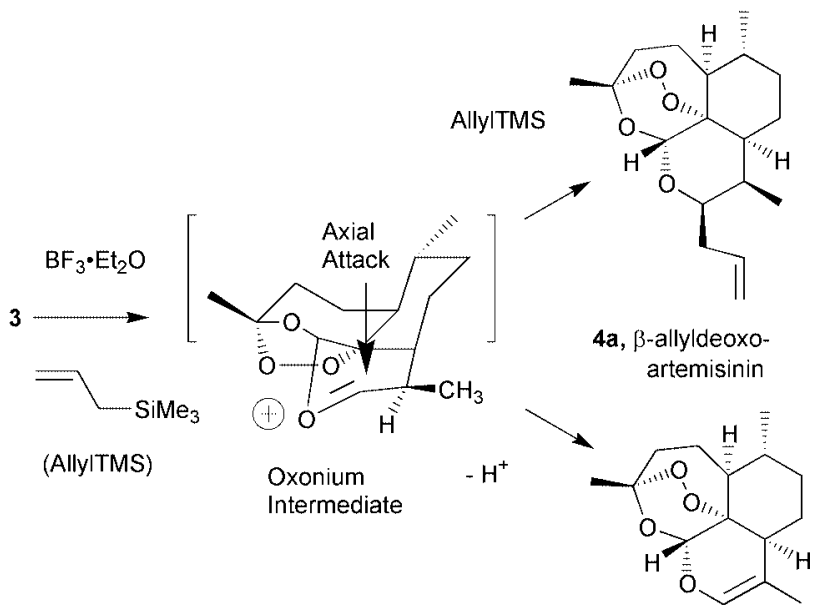

Scheme 1

4b. Anhydroartemisinin

The drawback in the procedure is the harsh nature of the Lewis acid, which results in the generation of substantial amounts of the dehydration product anhydroartemisinin $\mathbf{4 b}$ (AHA). This makes purification of the desired material extremely difficult on a large scale since $\mathbf{4 a}$ and $\mathbf{4 b}$ have very similar $R_{\mathrm{f}} \mathrm{s}$ on silica gel. We reasoned that a milder Lewis acid and a better anomeric leaving group would improve the yield of $4 \mathbf{a}$. In considering the choice of Lewis acid, we also noted that hard Lewis acids such as $\mathrm{BF}_{3} \cdot \mathrm{Et}_{2} \mathrm{O}$, have the capacity to rearrange target $\mathrm{C}-10$ carba derivatives whereas weaker Lewis acids such as zinc chloride do not. Indeed, in several large-scale runs using $\mathrm{BF}_{3} \cdot \mathrm{Et}_{2} \mathrm{O}$ as Lewis acid, several unwanted products were observed including the deoxygenated trioxane by-product shown in Scheme 2. ${ }^{20}$ The mechanism for the formation of this product is believed to involve an acid-catalysed $\mathrm{C}-\mathrm{O}$ migration. With these observations in mind, zinc chloride was chosen as a mild Lewis acid for the coupling reaction with C-10 $\alpha$-benzoate 5 .

The benzoate $\mathbf{5}$ was prepared in high yield by treatment of DHA with benzoyl chloride in pyridine. NMR studies on the white crystalline solid indicated $(\alpha)$ stereochemistry with respect to the $\mathrm{C}-\mathrm{O}$ linkage at $\mathrm{C}-10(\mathrm{C}-10 \mathrm{H}$ appears as a doublet with a $J_{9-10}$ value of $9.9 \mathrm{~Hz}$ indicating a dihedral angle of about $180^{\circ}$ between itself and C-9 H). After several runs using different temperatures and solvents, optimum conditions were found where the product could be obtained in high yields with only minor quantities of the by-product, $\mathbf{4 b}$. Thus, reaction of the benzoate with allyltrimethylsilane (5 equivalents) in the presence of $\mathrm{ZnCl}_{2}$ catalyst (1.2 equivalents) at $0{ }^{\circ} \mathrm{C}$ for $4 \mathrm{~h}$ gave the desired product, $\mathbf{4 a}$, in $90 \%$ yield (Scheme 3 ). This result suggests that the leaving group and Lewis acid are perfectly tuned for effecting controlled oxonium generation and subsequent reaction with allylsilanes as nucleophiles. Given the dramatic improvement in yield, we reasoned that this approach should be readily applicable to other reactive allylsilanes bearing lipophilic, fluorinated aromatic rings, substituents previously shown to improve the biological activity of peroxide based antimalarials. ${ }^{21-22}$ Two approaches were
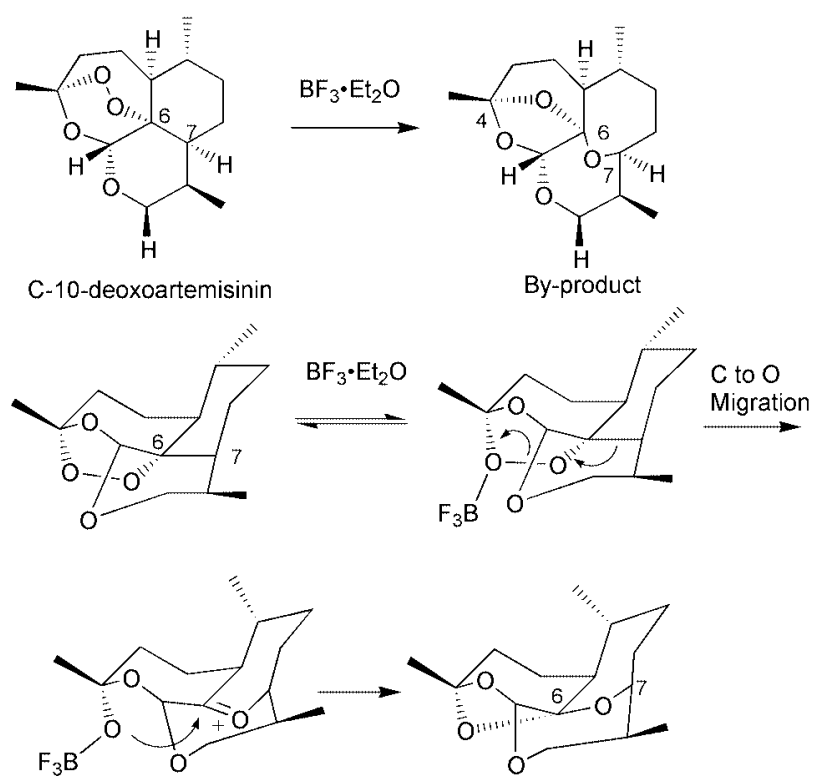

Scheme 2

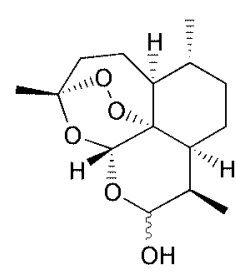

3

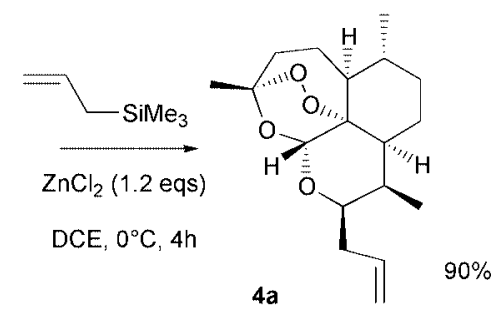

Scheme 3

considered for the preparation of requisite allylsilanes; (i) the cerium mediated conversion of esters to allylsilanes ${ }^{23}$ and (ii) $\mathrm{Ni}(\mathrm{acac})_{2}$ cross coupling of silylenol ethers with trimethylsilylmethylmagnesium chloride. ${ }^{24}$

\section{Preparation of allylsilanes}

Cerium mediated conversion of esters to allylsilanes. ${ }^{23}$ Recent interest has focused on the use of carboxylic acid derivatives as functional precursors for allylsilanes. ${ }^{23,25,26}$ The transformation includes twofold addition of a trimethylsilylmetal to the ester yielding the bis( $\beta$-silyl) alcohol, which on deoxysilylation leads to the allylsilane 7 (Scheme 4).

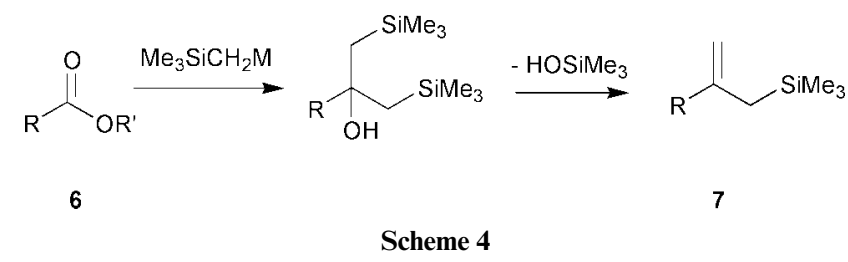

The reaction has been successful, although low yielding, for esters of unbranched carboxylic acids using trimethylsilylmethylmagnesium chloride. ${ }^{25}$ The reaction fails completely when using esters of $\alpha$-branched carboxylic acids ${ }^{25}$ where the $\alpha$-silyl-ketone intermediate resists further addition of Grignard 
in favour of kinetic enolization. Imamoto, however, has shown that organocerium reagents are especially suited for additions to readily enolized carbonyl systems. ${ }^{27}$ The reagent used in our reaction was therefore a preparation of $\mathrm{CeCl}_{3}$ and trimethylsilylmethylmagnesium chloride. Unfortunately this procedure proved very unreliable and frequently, very poor yields of target allylsilanes were obtained (Table 1). The variation in yields prompted us to investigate other methods for synthesising the required allylsilanes.

\section{Nickel-catalyzed cross-coupling of silyl enol ethers with Grignard reagents ${ }^{24}$}

In this reaction a silyl enol ether is allowed to react with a Grignard reagent in the presence of nickel acetylacetonate, $\mathrm{Ni}(\mathrm{acac})_{2}$, as catalyst. This gives the cross-coupled product in excellent yield. A range of silyl enol ethers were prepared from commercially available acetophenone derivatives and the resulting enol ethers converted into target allylsilanes. Yields for the synthesis of both silyl enol ethers and allylsilanes are recorded in Table 2.

The yields for the silyl enol ethers ranged from 60 to $80 \%$, with NMR and accurate mass spectrometry establishing the purity of the compounds. In most cases, good yields were achieved for the synthesis of target allylsilanes with one notable exception. No reaction was observed on trying to convert $9 \mathbf{c}$ to the desired allylsilane 10c. A possible explanation is that the large $p$-trifluoromethyl group is hindering insertion of the catalytically active nickel species into the styryl function of $\mathbf{9 c}$.

\section{Table 1}

\begin{tabular}{lll}
$\mathbf{6 a}$ & \\
\hline
\end{tabular}

\section{Deoxoartemisinin derivatives}

With a range of allylsilanes to hand, we then applied our optimized coupling conditions. C-10 benzoate $\mathbf{5}$ was allowed to react with a given allylsilane $(\mathbf{7 a}, 7 \mathbf{b}$ and $\mathbf{1 0 a}, \mathbf{b}, \mathbf{d}, \mathbf{e})$ in the presence of zinc chloride at $0{ }^{\circ} \mathrm{C}$ for approximately 4 hours. After extraction into DCM and washing with 5\% aqueous citric acid solution, column chromatography furnished the desired compounds as white foams in excellent yield and high purity. A generalised reaction is shown in Scheme 5 and the results are listed in Table 3.

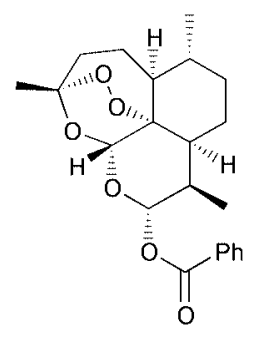

5
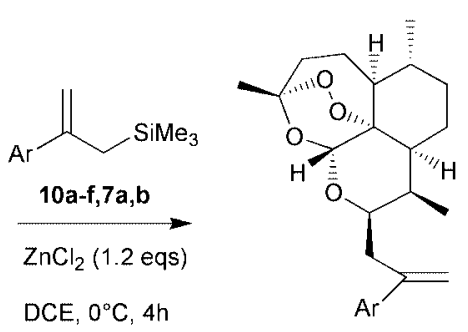

$11 \mathrm{a}-11 \mathrm{~g}, 70-94 \%$
Scheme 5

The observed stereochemistry in analogues $\mathbf{1 1 a}-\mathbf{1 1 g}$ is $(\beta)$ at the $\mathrm{C}-10$ carbon and this is in line with observations made by Ziffer ${ }^{10}$ using a mechanism proposed by $\mathrm{Kishi}^{28}$, where the nucleophile attacks 5 in an axial manner (Scheme 1). The high yields obtained for target carba analogues compares favourably with other approaches to this type of system. The presence of the $\mathrm{C}-\mathrm{C}$ linkage should ensure that these compounds have greater metabolic stability than the first generation derivatives artemether and arteether.

Three of the new compounds were tested in vitro versus the highly chloroquine resistant $\mathrm{K} 1$ strain of Plasmodium falciparum (Table 4). Compounds $\mathbf{1 1 f}$ and $\mathbf{1 1 g}$ were 10 times more potent than artemisinin and 3 fold more potent than artemether. Table 4 also includes data for chloroquine and allyldeoxoartemisinin 4a. The data clearly demonstrate that the incorporation of lipophilic fluorinated aryl rings is beneficial to antimalarial activity since $\mathbf{1 1 d}, \mathbf{1 1}$ and $\mathbf{1 1 g}$ are more active as antimalarials than $\mathbf{4 a}$.

Table $2 \mathrm{Ni}(\mathrm{acac})_{2}$ mediated synthesis of allylsilanes

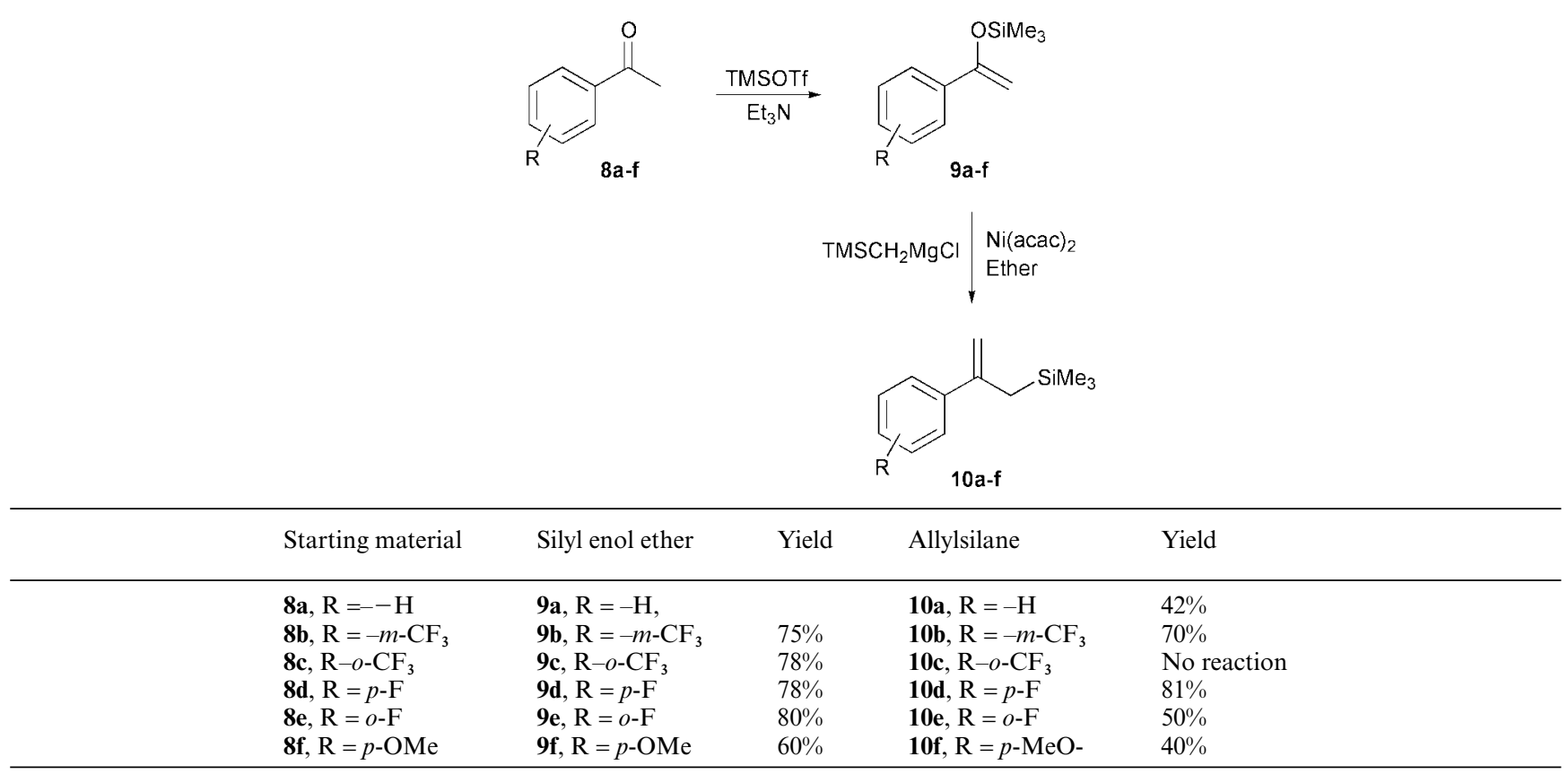


Table 3 Yields of C-10 deoxo analogues from allylsilanes

\begin{tabular}{clc}
\hline Allylsilane & C-10-deoxoartemisinin & Yield \\
\hline $\mathbf{1 0 a}$ & $\mathbf{1 1 a}, \mathrm{Ar}=\mathrm{Ph}$ & $91 \%$ \\
$\mathbf{1 0 b}$ & $\mathbf{1 1 b}, \mathrm{Ar}=m-\mathrm{CF}_{3}-\mathrm{Ph}$ & $94 \%$ \\
$\mathbf{1 0 d}$ & $\mathbf{1 1 d}, \mathrm{Ar}=p-\mathrm{F}-\mathrm{Ph}$ & $86 \%$ \\
$\mathbf{1 0 e}$ & $\mathbf{1 1 e}, \mathrm{Ar}=o-\mathrm{F}-\mathrm{Ph}$ & $70 \%$ \\
$\mathbf{7 a}$ & $\mathbf{1 1 f}, \mathrm{Ar}=p-C F_{3}$ & $81 \%$ \\
$\mathbf{7 b}$ & $\mathbf{1 1 g}, \mathrm{Ar}=m-\mathrm{F}-\mathrm{Ph}$ & $90 \%$ \\
\hline
\end{tabular}

Table 4 In vitro antimalarial activity of new analogues versus $\mathrm{K} 1$ Plasmodium falciparum

\begin{tabular}{ccl}
\hline Analogue & IC50 (nM) & $\mathrm{SD} \pm^{a}$ \\
\hline Artemisinin (2) & 17.1 & 4.2 \\
Artemether (3a) & 9.2 & 2.1 \\
$\mathbf{1 1 d}$ & 3.9 & 0.8 \\
$\mathbf{1 1 f}$ & 1.8 & 0.3 \\
$\mathbf{1 1 g}$ & 2.5 & 0.8 \\
$\mathbf{4 a}$ & 7.2 & 1.2 \\
${ }^{a} \mathrm{SD} \pm=$ standard deviation. & & \\
\hline
\end{tabular}

The generally accepted mechanism of action of peroxide antimalarials involves the interaction of the peroxidecontaining drug with haem, a haemoglobin degradation by-product, derived from proteolysis of haemoglobin. ${ }^{29}$ This interaction is believed to result in the formation of a range of potentially toxic oxygen and carbon-centred radicals. In order to gain deeper mechanistic insight into the "actual" radical intermediates or cytotoxic end-products generated, several workers have employed biomimetic Fe(II) mediated decompositions to simulate events in the ferrous rich parasite food vacuole. Surprisingly, ferrous mediated degradation of 11a provided as the main product, the formate $\mathbf{1 2}$ in $60 \%$ yield. $^{30}$ This type of product is not seen following identical degradation of artemisinin or the first generation compounds artemether or arteether (Scheme 6, A).

Intraparasitic release of dicarbonyl formate 12, could in theory be responsible for some of the antimalarial activity of these analogues. Indeed in an earlier study on simplified C-3aryl trioxanes 13a and 13b, Posner and co-workers demonstrated that $\mathrm{C}$-12- $\beta$-orientated simplified trioxane 13a degrades to a dicarbonyl function in a similar manner to that observed in this study. ${ }^{31}$ It was proposed that intraparasitic release of this potentially cross-linking dicarbonyl, could be responsible, in part, for the high activity of these analogues. Interestingly, from the mechanistic work of Posner and co-workers, the pathway of ferrous mediated degradation of the trioxane was governed by stereochemistry at the $\mathrm{C}-12$ position, since in contrast to 13a, $\mathrm{C}-12-\alpha$-orientated trioxane 13b generated products analogous to those seen with artemether and artemisinin (Scheme 6, B). The explanation as to why stereochemistry at the $\mathrm{C}-12$ position of simplified trioxanes and simply changing carbon for oxygen at the $\mathrm{C}-10$ position of artemisinin or ether derivatives, drives the ferrous mediated cascade toward these dicarbonyl products remains to be clarified.

In summary, we have now developed an optimised approach to $\mathrm{C}-10$-carba analogues which delivers the products in up to 94\% yield from the easily prepared C-10 benzoate of dihydroartemisinin. Some of these analogues are more than ten times more potent than artemisinin.

\section{Experimental}

\section{General}

${ }^{1} \mathrm{H}$ and ${ }^{13} \mathrm{C}$ NMR spectra were recorded on Bruker AC200 and Varian Gemini 300 spectrometers. Mass spectra were recorded

A) Influence of C-10 Substituent - Semisynthetic Analogues

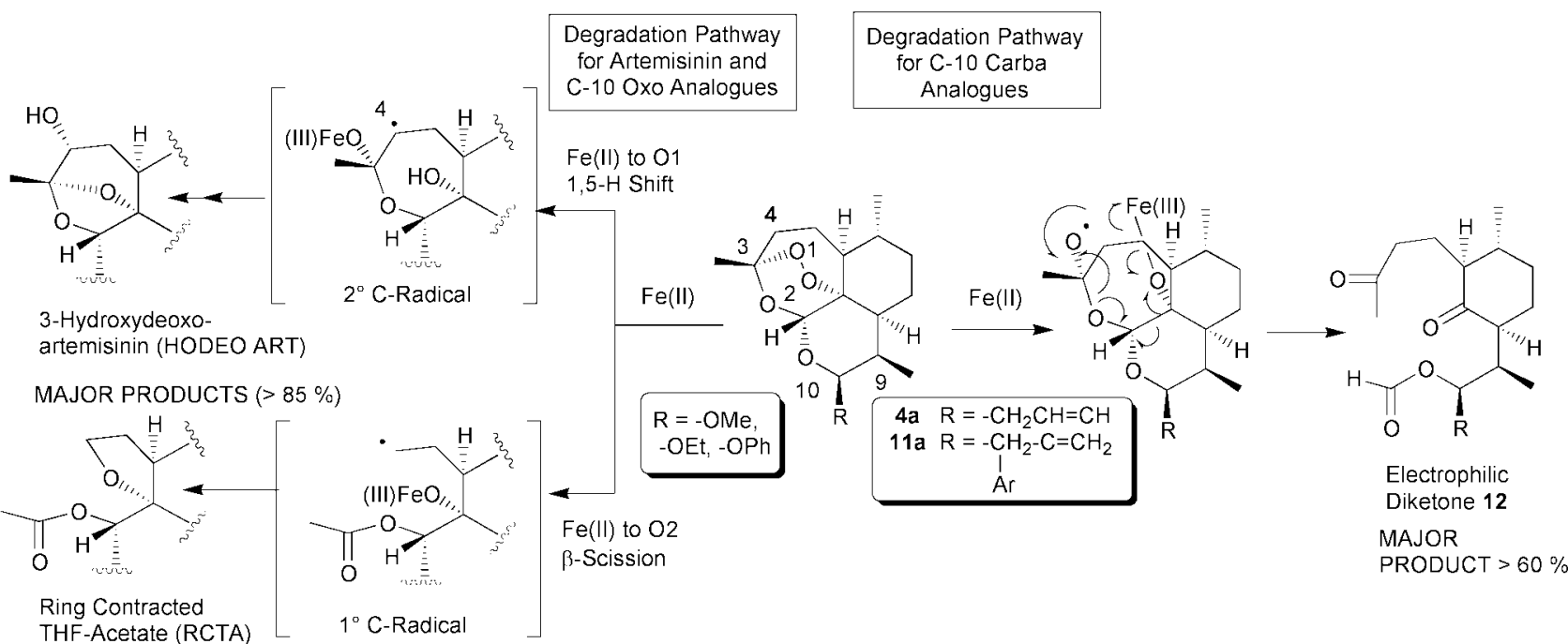

B) Influence of Stereochemistry - Synthetic Analogues

Stereochemical Dependent

Generation of a Diketone from

a Simplified Trioxane Analogue<smiles>C[C@@H]1O[C@H](C)[C@@H](C)O[C@H]1C</smiles><smiles>CC(=O)O[C@@H](C)[C@]1([18F])OCC[C@@H]1C</smiles>

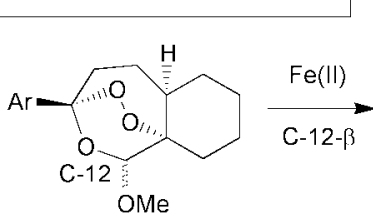

13a, C-12

13b, $\mathrm{C}-12 \propto$

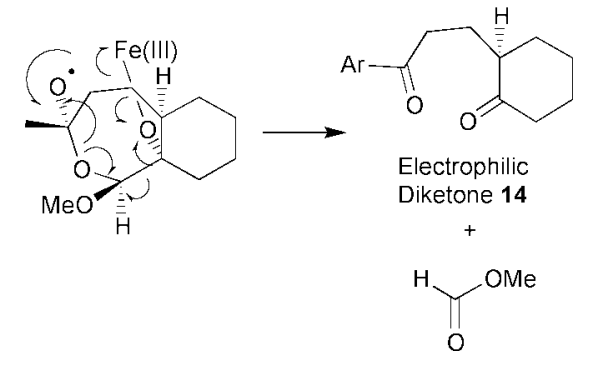

Scheme 6 
on VG analytical 7070E and Fisons TRIO 1000 spectrometers using electron ionisation (EI) and chemical ionisation (CI). Infrared spectra were recorded on a Perkin Elmer 1320 and Perkin Elmer FTIR Paragon 1000 spectrometers in the range of $4000-600 \mathrm{~cm}^{-1}$. Analytical TLC was performed on aluminiumbacked Merck silica gel $60 \mathrm{~F}_{254}$ plates. All liquid chromatography separations were performed using Merck Kieselgel 60 silica. Anhydrous DCM, DCE, diethyl ether, THF were purchased in sure-seal ${ }^{\mathrm{TM}}$ bottles from the Aldrich Chemical Company, and used as received. Acetonitrile was distilled from calcium hydride under nitrogen.

\section{General procedure 1: synthesis of silyl enol ethers}

To a solution of ketone starting material (1.0 eq.) in anhydrous ether $\left(2 \mathrm{~mL} \mathrm{mmol}^{-1}\right.$ of ketone) at $0{ }^{\circ} \mathrm{C}$ was added $\mathrm{Et}_{3} \mathrm{~N}$ (1.1 eq.) via a syringe. To this mixture, at $0{ }^{\circ} \mathrm{C}$, was slowly added TMSOTf (1.1 eq.) via a gas tight syringe. The resulting mixture was stirred at $0{ }^{\circ} \mathrm{C}$ for $15 \mathrm{~min}$, warmed to $\mathrm{rt}$, and stirred for 2 hours. Two phases were separated and the ethereal layer was concentrated under reduced pressure. The crude product was purified via Kugelrohr distillation to yield silyl enol ether with some starting material.

\section{General procedure 2: synthesis of allylsilanes ( $\mathrm{Ni}(\text { acac) })_{2}$ catalysed)}

To a mixture of trimethylsilylmethylmagnesium chloride in ether (12.5 eq.) and $\mathrm{Ni}(\mathrm{acac})_{2}$ (1.0 eq.) in anhydrous ether $(50 \mathrm{~mL})$ was added silyl enol ether starting material (6.3 eq.) at rt under a nitrogen atmosphere. The resulting black solution was heated under reflux for 3-6 hours and monitored by TLC ( $2 \%$ ethyl acetate in hexane). After hydrolysis with dilute hydrochloric acid, and extraction into DCM, the organic phase was washed with sodium bicarbonate and brine, dried with $\mathrm{MgSO}_{4}$ and concentrated under reduced pressure. The product was purified by flash column chromatography with hexane.

\section{General procedure 3: synthesis of allylsilanes $\left(\mathrm{CeCl}_{3}\right.$ method $)$}

Powdered $\mathrm{CeCl}_{3} \cdot 7 \mathrm{H}_{2} \mathrm{O}$ (5.4 eq.) was dried in a vacuum oven $\left(30 \mathrm{mmHg}, 160^{\circ} \mathrm{C}\right.$ ) overnight. The cooled flask was vented with nitrogen and anhydrous THF was added. The suspension was stirred at $\mathrm{rt}$ for $2 \mathrm{~h}$ before being cooled to $-70{ }^{\circ} \mathrm{C}$. Trimethylsilylmethylmagnesium chloride (5 eq.) was added via a syringe and the suspension left stirring for $1 \mathrm{~h}$, at which time the ester (1 eq.) was added over 2-3 min. Stirring was continued for $2 \mathrm{~h}$ at $-70{ }^{\circ} \mathrm{C}$ upon which time the reaction was allowed to warm to rt overnight. After quenching with hydrochloric acid (1 M), the crude product was isolated by extraction into DCM, drying over $\mathrm{MgSO}_{4}$ and solvent removal under reduced pressure. The product was purified by flash chromatography with hexane.

\section{General procedure 4: synthesis of deoxoartemisinin derivatives}

To a solution of allylsilane (4.8 eq.) in anhydrous DCE $(5 \mathrm{~mL})$ was added $\mathrm{ZnCl}_{2}$ (1.2 eq.) and $4 \AA$ molecular sieves under an inert nitrogen atmosphere. The mixture was cooled to $0{ }^{\circ} \mathrm{C}$ before adding a solution of benzoate (1 eq. in DCE $(5 \mathrm{~mL})$ ) and leaving to stir at $0{ }^{\circ} \mathrm{C}$ for $4 \mathrm{~h}$. After quenching with $5 \%$ aq. citric acid solution and separating the organic phase, the crude product was extracted from the aqueous layer into ethyl acetate. The combined organic extracts were washed with saturated $\mathrm{NaHCO}_{3}$ and brine, dried over $\mathrm{MgSO}_{4}$ and the solvent removed under reduced pressure. The product was purified by flash chromatography with hexane and ethyl acetate $(10: 1)$ as eluent.

\section{Dihydroartemisinin 10a-benzoate 5}

To a solution of DHA $(5.0 \mathrm{~g}, 1.76 \mathrm{~mol})$ in anhydrous DCM $(54 \mathrm{~mL})$ under an inert nitrogen atmosphere was added anhydrous pyridine $(9 \mathrm{~mL})$. The mixture was cooled to $0{ }^{\circ} \mathrm{C}$ before adding benzoyl chloride $(3.17 \mathrm{~mL} 2.73 \mathrm{~mol})$. After stirring at $0{ }^{\circ} \mathrm{C}$ for $15 \mathrm{~min}$, the reaction mixture was allowed to warm to $\mathrm{rt}$ and was left for $16 \mathrm{~h}$. The reaction was quenched with $7 \%$ aq. citric acid solution and the aqueous phase extracted with ethyl acetate $(3 \times 100 \mathrm{~mL})$. The combined organic extracts were washed with $7 \%$ aq. citric acid solution followed by saturated $\mathrm{NaHCO}_{3}$ and finally dried over $\mathrm{MgSO}_{4}$. The crude mixture was recrystallised from diethyl ether and hexane $(1: 1)$ at $0{ }^{\circ} \mathrm{C}$ to yield white crystals $(4.14 \mathrm{~g}, 61 \%$ yield $)$. $v_{\max }$ (Nujol mull)/cm ${ }^{-1} 2927,1737,1492,1453,1113,876 ;{ }^{1} \mathrm{H}$ NMR $\left(300 \mathrm{MHz}, \mathrm{CDCl}_{3}\right) \delta 8.14-8.11(2 \mathrm{H}, \mathrm{m}, \mathrm{Ar}), 7.57(1 \mathrm{H}, \mathrm{m}$, $\mathrm{Ar}), 7.47-7.42(2 \mathrm{H}, \mathrm{m}, \mathrm{Ar}), 6.02(1 \mathrm{H}, \mathrm{d}, J=9.9 \mathrm{~Hz}, 10-\mathrm{H}), 5.53$ $(1 \mathrm{H}, \mathrm{s}, 12-\mathrm{H}), 2.76(1 \mathrm{H}, \mathrm{m}, 9-\mathrm{H}), 2.40(1 \mathrm{H}, \mathrm{dt}, J=12.9,4.0 \mathrm{~Hz})$, $2.04(1 \mathrm{H}, \mathrm{m}), 1.94-1.20(9 \mathrm{H}, \mathrm{m}), 1.43\left(3 \mathrm{H}, \mathrm{s}, \mathrm{CH}_{3}\right.$ at $\left.\mathrm{C} 3\right), 0.98$ $\left(3 \mathrm{H}, \mathrm{d}, J=6.0 \mathrm{~Hz}, \mathrm{CH}_{3}\right), 0.93\left(3 \mathrm{H}, J=7.2 \mathrm{~Hz}, \mathrm{CH}_{3}\right) ;{ }^{13} \mathrm{C} \mathrm{NMR}$ $\left(75 \mathrm{MHz}, \mathrm{CDCl}_{3}\right) \delta 165.45,133.38,130.21,129.79,128.39$, 104.46, 92.60, 91.64, 80.19, 51.66, 45.34, 37.22, 36.23, 34.09, 31.94, 25.86, 24.52, 21.98, 20.13, 12.11; MS m/z (CI, $\left.\mathrm{NH}_{3}\right) 284.3$ (35\%), 267.3 (55), 249.2 (15), 238.3 (18), 221.2 (100), 207.2 (80), 162.2 (31), 149.1 (7), 105.1 (16); Found 406.22436. $\mathrm{C}_{22} \mathrm{H}_{32} \mathrm{NO}_{6}$ $\left[\mathrm{M}+\mathrm{NH}_{4}\right]^{+}$requires 406.2296, found: $\mathrm{C}, 68.03 ; \mathrm{H}, 7.25$; requires $\mathrm{C}, 68.02 ; \mathrm{H}, 7.26 \%$.

\section{Trimethyl[2-(4-trifluoromethylphenyl)allyl]silane 7a}

This was synthesised in accordance to general procedure 3 using 4-trifluoromethylbenzoic acid methyl ester $(0.16 \mathrm{~mL}$, $1.0 \mathrm{mmol})$. Purification of the product resulted in a clear oil $\left(0.17 \mathrm{~g}, 67 \%\right.$ yield). $v_{\max }$ (neat) $/ \mathrm{cm}^{-1} 3092.0,1618.0,1280.0$, 1015.0, 846.0; ${ }^{1} \mathrm{H}$ NMR $\left(300 \mathrm{MHz}, \mathrm{CDCl}_{3}\right) \delta 7.57-7.48(4 \mathrm{H}, \mathrm{m}$, Ar), $5.18(1 \mathrm{H}, \mathrm{d}, J=1.5 \mathrm{~Hz}), 4.96(1 \mathrm{H}, \mathrm{d}, J=0.9 \mathrm{~Hz}), 2.02(2 \mathrm{H}$, $\mathrm{d}, J=1.2 \mathrm{~Hz}),-0.10(9 \mathrm{H}, \mathrm{s}) ;{ }^{13} \mathrm{C} \mathrm{NMR}\left(75 \mathrm{MHz}, \mathrm{CDCl}_{3}\right)$ $\delta 148.03,147.17,130.61,128.13,127.64,126.64\left(1 \mathrm{C}, \mathrm{d}, J_{\mathrm{C}-\mathrm{F}}=\right.$ $3.8 \mathrm{~Hz}), 113.53,27.51,0.00$; MS m/z (EI) 243 (6.25\%), 203 (7.11), 166 (32.57), 165 (19.14), 164 (6.07), 146 (5.89), 145 (9.43), 116 (9.43), 115 (14.71), 75 (7.50), 74 (8.21), 73 (100.00), 45 (12.71), 43 (11.00); Found 258.10512. $\mathrm{C}_{13} \mathrm{H}_{17} \mathrm{SiF}_{3}$ requires 258.10516 .

\section{[2-(3-Fluorophenyl)allyl]trimethylsilane $7 \mathrm{~b}$}

This was synthesised in accordance to general procedure 3 using ethyl 3-fluorobenzoate $(0.15 \mathrm{~mL}, 1.0 \mathrm{mmol})$. Purification of the product resulted in a clear oil $(0.15 \mathrm{~g}, 73 \%$ yield $) . v_{\max }$ (neat) $/ \mathrm{cm}^{-1} 3090.0,1611.0,1265.0,1159.0,875.0,851.0 ;{ }^{1} \mathrm{H}$ NMR (300 MHz, CDCl $)_{3} \delta$ 7.38-6.99 (4H, m, Ar), $5.24(1 \mathrm{H}, \mathrm{d}$, $J=1.5 \mathrm{~Hz}), 4.99(1 \mathrm{H}, \mathrm{d}, J=1.2 \mathrm{~Hz}), 2.07(2 \mathrm{H}, \mathrm{s}), 0.00(9 \mathrm{H}, \mathrm{s})$; ${ }^{13} \mathrm{C} \mathrm{NMR}\left(75 \mathrm{MHz}, \mathrm{CDCl}_{3}\right) \delta 162.86\left(1 \mathrm{C}, \mathrm{d}, J_{\mathrm{C}-\mathrm{F}}=243.5 \mathrm{~Hz}\right)$, $145.60,145.28\left(1 \mathrm{C}, \mathrm{d}, J_{\mathrm{C}-\mathrm{F}}=7.1 \mathrm{~Hz}\right), 129.50\left(1 \mathrm{C}, \mathrm{d}, J_{\mathrm{C}-\mathrm{F}}=\right.$ $8.1 \mathrm{~Hz}), 122.02,113.95\left(1 \mathrm{C}, \mathrm{d}, J_{\mathrm{C}-\mathrm{F}}=21.3 \mathrm{~Hz}\right), 113.25(1 \mathrm{C}, \mathrm{d}$, $\left.J_{\mathrm{C}-\mathrm{F}}=21.8 \mathrm{~Hz}\right), 111.00,26.02,1.53$; MS $\mathrm{m} / z$ (EI) $193(15.30 \%)$, 177 (6.09), 153 (18.66), 115 (24.00), 77 (7.65), 75 (6.25), 74 (7.65), 73 (100.00), 45 (8.46), 43 (6.90); Found 208.10834. $\mathrm{C}_{12} \mathrm{H}_{17} \mathrm{SiF}$ requires 208.10835; found: C, 69.12; H, 8.25; requires $\mathrm{C}, 69.18 ; \mathrm{H}, 8.22 \%$.

\section{Trimethyl[1-(3-trifluoromethylphenyl)vinyloxy]silane 9b}

This was synthesised in accordance to general procedure 1 using 3-(trifluoromethyl)acetophenone (1.83 mL, $12 \mathrm{mmol})$. Purification of the product by Kugelrohr distillation $\left(70{ }^{\circ} \mathrm{C}\right.$, $0.1 \mathrm{mmHg}$ ) resulted in a clear oil in $75 \%$ yield. ${ }^{1} \mathrm{H} \mathrm{NMR}$ $\left(300 \mathrm{MHz}, \mathrm{CDCl}_{3}\right) \delta 8.15-7.20(4 \mathrm{H}, \mathrm{m}, \mathrm{Ar}), 4.91(1 \mathrm{H}, \mathrm{d}, J=$ $2.1 \mathrm{~Hz}), 4.49(1 \mathrm{H}, \mathrm{d}, J=2.1 \mathrm{~Hz}), 0.00(9 \mathrm{H}, \mathrm{s}) ; \mathrm{MS} m / z(\mathrm{EI}) 245$ (31.8\%), 191 (16.64), 188 (12.92), 173 (100.00), 169 (13.48), 151 (15.73), 145 (66.57), 103 (17.98), 75 (30.34), 73 (12.50), 47 (10.39), 43 (14.40); Found 260.08330. $\mathrm{C}_{12} \mathrm{H}_{15} \mathrm{~F}_{3} \mathrm{OSi}$ requires 260.08441 .

\section{Trimethyl[1-(2-trifluoromethylphenyl)vinyloxy]silane 9c}

This was synthesised in accordance to general procedure 1 using 2-(trifluoromethyl)acetophenone (1.83 mL, $12 \mathrm{mmol})$. 
Purification of the product by Kugelrohr distillation $\left(50-55^{\circ} \mathrm{C}\right.$, $0.1 \mathrm{mmHg})$ resulted in a clear oil $(2.42 \mathrm{~g}, 78 \%$ yield $) .{ }^{1} \mathrm{H}$ NMR $\left(200 \mathrm{MHz}, \mathrm{CDCl}_{3}\right) \delta 7.63-7.19(4 \mathrm{H}, \mathrm{m}, \mathrm{Ar}), 4.43(1 \mathrm{H}, \mathrm{d}, J=$ $1.6 \mathrm{~Hz}), 4.37(1 \mathrm{H}, \mathrm{d}, J=1.6 \mathrm{~Hz}), 0.17(9 \mathrm{H}, \mathrm{s}) ; \mathrm{MS} m / z(\mathrm{CI}$, $\left.\mathrm{NH}_{3}\right) 245.0$ (10\%), 206.1 (50), 191.1 (15), 173.0 (60), 149.0 (24), 90.0 (100.0); Found 261.09329. $\mathrm{C}_{12} \mathrm{H}_{16} \mathrm{OF}_{3} \mathrm{Si}[\mathrm{M}+\mathrm{H}]^{+}$requires 261.09225 .

\section{[1-(4-Fluorophenyl)vinyloxy]trimethylsilane 9d}

This was synthesised in accordance to general procedure 1 using 4-fluoroacetophenone (1.46 mL, $12 \mathrm{mmol})$. Purification of the product by Kugelrohr distillation $\left(70-75^{\circ} \mathrm{C}, 0.1 \mathrm{mmHg}\right)$ resulted in a clear oil $(1.71 \mathrm{~g}, 68 \%$ yield $) .{ }^{1} \mathrm{H}$ NMR $(200 \mathrm{MHz}$, $\left.\mathrm{CDCl}_{3}\right) \delta 7.24-6.93(4 \mathrm{H}, \mathrm{m}, \mathrm{Ar}), 4.81(1 \mathrm{H}, \mathrm{d}, J=1.9 \mathrm{~Hz}), 4.37$ $(1 \mathrm{H}, \mathrm{d}, J=1.4 \mathrm{~Hz}), 0.24(9 \mathrm{H}, \mathrm{s})$.

\section{[1-(2-Fluorophenyl)vinyloxy]trimethylsilane 9e}

This was synthesised in accordance to general procedure 1 using 2-fluoroacetophenone (1.48 mL, $12 \mathrm{mmol})$. Purification of the product by Kugelrohr distillation $\left(60-65^{\circ} \mathrm{C}, 0.1 \mathrm{mmHg}\right)$ resulted in a clear oil $(2.01 \mathrm{~g}, 80 \%$ yield $) .{ }^{1} \mathrm{H}$ NMR $(300 \mathrm{MHz}$, $\left.\mathrm{CDCl}_{3}\right) \delta 7.34-7.23(1 \mathrm{H}, \mathrm{m}, \mathrm{Ar}), 7.03-6.75(3 \mathrm{H}, \mathrm{m}, \mathrm{Ar}), 4.97$ $(1 \mathrm{H}, \mathrm{s}), 4.63(1 \mathrm{H}, \mathrm{d}, J=1.5 \mathrm{~Hz}), 0.20(9 \mathrm{H}, \mathrm{s}) ;{ }^{13} \mathrm{C} \mathrm{NMR}$ $\left(75 \mathrm{MHz}, \mathrm{CDCl}_{3}\right) \delta 160.19\left(1 \mathrm{C}, \mathrm{d}, J_{\mathrm{C}-\mathrm{F}}=249.5 \mathrm{~Hz}\right), 150.50$, $129.41\left(1 \mathrm{C}, \mathrm{d}, J_{\mathrm{C}-\mathrm{F}}=8.7 \mathrm{~Hz}\right), 128.88,123.74\left(1 \mathrm{C}, \mathrm{d}, J_{\mathrm{C}-\mathrm{F}}=\right.$ $3.3 \mathrm{~Hz}), 115.98\left(1 \mathrm{C}, \mathrm{d}, J_{\mathrm{C}-\mathrm{F}}=23.5 \mathrm{~Hz}\right), 97.2\left(1 \mathrm{C}, \mathrm{d}, J_{\mathrm{C}-\mathrm{F}}=\right.$ $11.0 \mathrm{~Hz}$ ), 30.83, 0.00; MS m/z (EI) 209 (36.44\%), 195 (59.48), 173 (23.69), 77 (100.00), 73 (22.71); Found 210.08710. $\mathrm{C}_{11} \mathrm{H}_{15} \mathrm{OFSi}$ requires 210.08762 .

\section{[1-(4-Methoxyphenyl)vinyloxy]trimethylsilane 9f}

This was synthesised in accordance to general procedure 1 using 4-methoxyacetophenone (1.80 g, $12 \mathrm{mmol})$. Purification of the product by Kugelrohr distillation resulted in a orange oil (1.66 g, 59\% yield). ${ }^{1} \mathrm{H}$ NMR $\left(200 \mathrm{MHz}, \mathrm{CDCl}_{3}\right) \delta 7.95-6.82$ $(4 \mathrm{H}, \mathrm{m}, \mathrm{Ar}), 4.79(1 \mathrm{H}, \mathrm{s}), 4.32(1 \mathrm{H}, \mathrm{s}), 3.79(3 \mathrm{H}, \mathrm{s}), 0.25(9 \mathrm{H}, \mathrm{s})$.

\section{Trimethyl(2-phenylallyl)silane 10a}

This was synthesised in accordance to general procedure 2 using 1-phenyl-1-(trimethylsiloxy)ethylene 9a (0.96 g, 5.0 $\mathrm{mmol})$. Purification of the product resulted in a clear oil $(0.40 \mathrm{~g}$, $42 \%$ yield). ${ }^{1} \mathrm{H}$ NMR $\left(300 \mathrm{MHz}, \mathrm{CDCl}_{3}\right) \delta 7.47-7.21(5 \mathrm{H}, \mathrm{m}$, Ar), $5.12(1 \mathrm{H}, \mathrm{br} \mathrm{s}), 4.86(1 \mathrm{H}, \mathrm{br} \mathrm{s}), 2.21(2 \mathrm{H}, \mathrm{br} \mathrm{s}), 0.18(9 \mathrm{H}, \mathrm{s})$; ${ }^{13} \mathrm{C}$ NMR $\left(75 \mathrm{MHz}, \mathrm{CDCl}_{3}\right) \delta 151.78,128.17,127.36,126.41$, 125.56, 110.10, 20.91, 0.00; found: C, 74.83; H, 9.41; requires C, 75.72; H, $9.53 \%$.

\section{Trimethyl[2-(3-trifluoromethylphenyl)allyl]silane 10b}

This was synthesised in accordance to general procedure 2 using $9 \mathbf{b}(1.30 \mathrm{~g}, 5.0 \mathrm{mmol})$. Purification of the product resulted in a yellow liquid $\left(0.70 \mathrm{~g}, 50 \%\right.$ yield). $v_{\max }$ (neat) $/ \mathrm{cm}^{-1} 2960.0$, 1620.0, 1281.0, 1128.0, 854.0; ${ }^{1} \mathrm{H}$ NMR (300 MHz, $\left.\mathrm{CDCl}_{3}\right)$ $\delta$ 8.54-7.27 (4H, m, Ar), $5.26(1 \mathrm{H}$, br s), $4.97(1 \mathrm{H}$, br s $), 2.04$ (2H, br s), $0.08(9 \mathrm{H}, \mathrm{s}) ;{ }^{13} \mathrm{C} \mathrm{NMR}\left(75 \mathrm{MHz}, \mathrm{CDCl}_{3}\right) \delta 145.45$, $143.61,129.58,128.61,123.88,123.11,111.60,26.04,-1.52$ MS m/z (EI) $243(12.22 \%), 167$ (5.05), 166 (47.41), 165 (20.19), 164 (5.56), 146 (9.58), 116 (11.81), 115 (17.78), 77 (11.85), 75 (5.00), 74 (7.41), 73 (100.00), 45 (11.62), 43 (7.87); Found 258.10487. $\mathrm{C}_{13} \mathrm{H}_{17} \mathrm{~F}_{3} \mathrm{Si}$ requires 258.10516.

\section{[2-(4-Fluorophenyl)allyl]trimethylsilane 10d}

This was synthesised in accordance to general procedure 2 using $9 d$ ( $1.05 \mathrm{~g}, 5.0 \mathrm{mmol})$. Purification of the product resulted in a yellow liquid $(0.84 \mathrm{~g}, 81 \%$ yield $) . v_{\max }$ (neat) $/ \mathrm{cm}^{-1} 2958.0$, 1603.0, 1248.0, 1160.0, 838.0; ${ }^{1} \mathrm{H}$ NMR (300 $\mathrm{MHz}, \mathrm{CDCl}_{3}$ ) $\delta 7.20-6.95(2 \mathrm{H}, \mathrm{m}, \mathrm{Ar}), 7.20-6.95(2 \mathrm{H}, \mathrm{m}, \mathrm{Ar}), 5.07(1 \mathrm{H}, \mathrm{d}, J=$ $1.5 \mathrm{~Hz}), 4.85(1 \mathrm{H}, \mathrm{d}, J=0.9 \mathrm{~Hz}), 1.99(2 \mathrm{H}, \mathrm{d}, J=1.2 \mathrm{~Hz}), 0.09$
$(9 \mathrm{H}, \mathrm{s}) ;{ }^{13} \mathrm{C} \mathrm{NMR}\left(75 \mathrm{MHz}, \mathrm{CDCl}_{3}\right) \delta 145.69,127.95,115.01$, 114.73, 110.03, 26.33, -1.51; MS m/z (EI) 193 (5.51\%), 153 (10.53), 115 (9.46), 75 (6.58), 74 (6.83), 73 (100.00), 45 (10.28); Found 208.10854. $\mathrm{C}_{12} \mathrm{H}_{17} \mathrm{FSi}$ requires 208.10835; found: C, 69.33; $\mathrm{H}, 8.28$; requires $\mathrm{C}, 69.18 ; \mathrm{H}, 8.22 \%$.

\section{[2-(2-Fluorophenyl)allyl]trimethylsilane 10e}

This was synthesised in accordance to general procedure 2 using $9 \mathrm{e}(1.05 \mathrm{~g}, 5.0 \mathrm{mmol})$. Purification of the product resulted in a yellow liquid $\left(0.57 \mathrm{~g}, 50 \%\right.$ yield). $v_{\max }$ (Nujol mull) $/ \mathrm{cm}^{-1}$ 2958.0, 1622.0, 1249.0, 1164.0, 880.0, 851.0; ${ }^{1} \mathrm{H}$ NMR $(300$ $\left.\mathrm{MHz}, \mathrm{CDCl}_{3}\right) \delta 7.30-6.99$ (4H, m, Ar), 5.02 (2H, br s), 2.05 $(2 \mathrm{H}, \mathrm{br} \mathrm{s}), 0.11(9 \mathrm{H}, \mathrm{s}) ;{ }^{13} \mathrm{C} \mathrm{NMR}\left(75 \mathrm{MHz}, \mathrm{CDCl}_{3}\right) \delta 142.68$, $130.06,128.65,123.84,115.88,115.58,113.79,30.84,27.43$, -1.71; MS m/z (EI) 116 (9.85\%), 115 (30.61), 77 (17.27), 74 (7.69), 73 (100.00), 45 (7.58); Found 208.10875. $\mathrm{C}_{12} \mathrm{H}_{17} \mathrm{FSi}$ requires 208.10835; found: $\mathrm{C}, 68.46$; $\mathrm{H}, 8.53$; requires $\mathrm{C}, 69.18$; $\mathrm{H}, 8.22 \%$.

\section{[2-(4-Methoxyphenyl)allyl]trimethylsilane $10 \mathrm{f}$}

This was synthesised in accordance to general procedure 2 using $9 \mathrm{f}(1.11 \mathrm{~g}, 5.0 \mathrm{mmol})$. Purification of the product resulted in a orange liquid $\left(0.41 \mathrm{~g}, 35 \%\right.$ yield). $v_{\max }$ (Nujol mull) $/ \mathrm{cm}^{-1}$ 2957.0, 2850.0, 1608.0, 1248.0, 833.0; ${ }^{1} \mathrm{H}$ NMR (300 MHz, $\left.\mathrm{CDCl}_{3}\right) \delta$ 7.44-7.41 (2H, m, Ar), 6.89-6.84 (2H, m), $5.28(1 \mathrm{H}$, br s), 5.00 (1H, brs ), $3.82(3 \mathrm{H}, \mathrm{s}), 2.14(2 \mathrm{H}, \mathrm{br} \mathrm{s}), 0.19(9 \mathrm{H}, \mathrm{s})$; ${ }^{13} \mathrm{C}$ NMR $\left(75 \mathrm{MHz}, \mathrm{CDCl}_{3}\right) \delta 126.66,113.63,110.69,55.30$, 21.88, 0.05; MS m/z (EI) 205 (29.36\%), 165 (100.00), 73 (37.77); Found 220.12852. $\mathrm{C}_{13} \mathrm{H}_{20} \mathrm{SiO}$ requires 220.12834.

\section{0ק-Allyldeoxoartemisinin 4a}

This was synthesised in accordance to general procedure 4 using allyltrimethylsilane to give the product as a white solid $\left(90 \%, \mathrm{mp} 77-79^{\circ} \mathrm{C}\right)$. The physical properties were identical to those reported in ref. 8.

\section{Anhydroartemisinin 4b}

$v_{\max }$ (Nujol mull)/(cm ${ }^{-1} 2923.9,2852.4,1685.9,1459.9,1112.8$, 880.2; ${ }^{1} \mathrm{H} \mathrm{NMR}\left(300 \mathrm{MHz}, \mathrm{CDCl}_{3}\right) \delta 6.19(1 \mathrm{H}, \mathrm{s}, 10-\mathrm{H}), 5.42$ $(1 \mathrm{H}, \mathrm{s}, 12-\mathrm{H}), 2.41(1 \mathrm{H}, \mathrm{dt}, J=13.9,4.8 \mathrm{~Hz}), 2.04(2 \mathrm{H}, \mathrm{m})$, $1.92(1 \mathrm{H}, \mathrm{m}), 1.74-1.36(5 \mathrm{H}, \mathrm{m}), 1.59\left(3 \mathrm{H}, \mathrm{d}, J=1.2, \mathrm{CH}_{3}\right)$, $1.42\left(3 \mathrm{H}, \mathrm{s}, \mathrm{CH}_{3}\right.$ at $\left.\mathrm{C} 3\right), 1.14(2 \mathrm{H}, \mathrm{m}), 0.98(3 \mathrm{H}, \mathrm{d}, J=6.0 \mathrm{~Hz}$, $\left.\mathrm{CH}_{3}\right) ;{ }^{13} \mathrm{C}\left(75 \mathrm{MHz}, \mathrm{CDCl}_{3}\right) \delta 135.12,108.11,104.56,89.74$ (C10), 78.99, 51.50, 44.50, 37.50, 36.27, 34.14, 30.00, 25.89, $24.42,20.25,16.14$.

\section{0ß-(2-Phenylallyl)deoxoartemisinin 11a}

This was synthesised in accordance to general procedure 4 using 10a $(0.39 \mathrm{~g}, 2.0 \mathrm{mmol})$. Purification of the product resulted in a white glue $\left(0.14 \mathrm{~g}, 91 \%\right.$ yield). $v_{\max }$ (Nujol mull)/ $\mathrm{cm}^{-1}$ 2927.0, 1463.0, 1104.0, 895.0; ${ }^{1} \mathrm{H}$ NMR (300 MHz, $\left.\mathrm{CDCl}_{3}\right) \delta 7.42-7.24(5 \mathrm{H}, \mathrm{m}, \mathrm{Ar}), 5.36(2 \mathrm{H}, \mathrm{br} \mathrm{s}), 5.27(1 \mathrm{H}, \mathrm{d}$, $J=1.4 \mathrm{~Hz}), 4.52(1 \mathrm{H}, \mathrm{m}, 10-\mathrm{H}), 2.72-1.20(17 \mathrm{H}, \mathrm{m}), 0.97-0.92$ $(6 \mathrm{H}, \mathrm{m}) ;{ }^{13} \mathrm{C}$ NMR $\left(75 \mathrm{MHz}, \mathrm{CDCl}_{3}\right) \delta 128.26,127.30,126.47$, 114.36, 102.80 (C12), 89.65 (C10), 71.70, 52.18, 44.24, 37.53, $36.69,35.85,34.49,30.48,25.75,24.93,20.09,12.73$; MS $\mathrm{m} / \mathrm{z}$ (EI) $338(23.84 \%), 165$ (20.93), 163 (44.19), 162 (100.00), 157 (24.61), 145 (28.49), 138 (21.12), 129 (24.42), 124 (21.32), 118 (36.82), 117 (31.20), 115 (35.85), 105 (43.02), 103 (31.98), 95 (32.56), 93 (22.29), 91 (58.14), 81 (32.56), 79 (23.06), 77 (31.78), 71 (23.84), 69 (36.24), 67 (23.84), 55 (51.94), 45 (88.37), 41 (35.66); Found 384.22957. $\mathrm{C}_{24} \mathrm{H}_{32} \mathrm{O}_{4}$ requires 384.23004; found: C, 73.89; H, 8.31; requires C, 74.97; $\mathrm{H}, 8.39 \%$.

\section{0ß-[2-(3-Trifluoromethylphenyl)allyl]deoxoartemisinin 11b}

This was synthesised in accordance to general procedure 4 using 10b $(0.56 \mathrm{~g}, 2.2 \mathrm{mmol})$. Purification of the product 
resulted in a white glue $\left(0.24 \mathrm{~g}, 94 \%\right.$ yield). $v_{\max }$ (Nujol mull)/ $\mathrm{cm}^{-1} 2923.1,1456.6,1376.9,1123.1,880.7 ;{ }^{1} \mathrm{H}$ NMR $(300$ $\left.\mathrm{MHz} \mathrm{CDCl}_{3}\right) \delta 7.71-7.42(4 \mathrm{H}, \mathrm{m}, \mathrm{Ar}), 5.42(1 \mathrm{H}, \mathrm{s}), 5.37(1 \mathrm{H}, \mathrm{s}$, $12-\mathrm{H}), 5.35(1 \mathrm{H}, \mathrm{s}), 4.52(1 \mathrm{H}, \mathrm{m}, 10-\mathrm{H}), 2.62(1 \mathrm{H}, \mathrm{m}, 9-\mathrm{H}), 2.28$ $(1 \mathrm{H}, \mathrm{dt}, J=13.9,4.0 \mathrm{~Hz}), 2.06-1.20(12 \mathrm{H}, \mathrm{m}), 1.25\left(3 \mathrm{H}, \mathrm{s}, \mathrm{CH}_{3}\right.$ at $\mathrm{C} 3), 0.98\left(3 \mathrm{H}, \mathrm{d}, J=5.7 \mathrm{~Hz}, \mathrm{CH}_{3}\right), 0.96(3 \mathrm{H}, \mathrm{d}, J=7.8 \mathrm{~Hz}$, $\left.\mathrm{CH}_{3}\right) ;{ }^{13} \mathrm{C}$ NMR $\left(75 \mathrm{MHz}, \mathrm{CDCl}_{3}\right) \delta 145.02,142.38,129.74$ $128.72,123.99,123.35,116.03,102.79(\mathrm{C} 12), 89.72(\mathrm{C} 10)$, $81.02,71.42,52.10,44.11,37.54,36.64,35.88,34.44,30.48$, 25.67, 24.92, 24.79, 20.06, 12.59; MS $m / z$ (EI) $163(25.00 \%), 162$ (53.19), 124 (23.01), 109 (20.74), 95 (28.46), 93 (23.54), 81 (27.79), 79 (21.68), 71 (20.61), 69 (31.38), 67 (24.20), 55 (59.04), 43 (100.00), 41 (36.17); Found 452.21724. $\mathrm{C}_{25} \mathrm{H}_{31} \mathrm{O}_{4} \mathrm{~F}_{3}$ requires 452.21744 .

\section{0ß-[2-(4-Fluorophenyl)allyl]deoxoartemisinin 11d}

This was synthesised in accordance to general procedure 4 using 10d (0.66 g, $3.2 \mathrm{mmol})$. Purification of the product resulted in a clear glue $\left(0.26 \mathrm{~g}, 86 \%\right.$ yield). $v_{\max }$ (Nujol mull)/ $\mathrm{cm}^{-1}$ 2922.7, 1455.9, 1375.8, 1125.9, 879.8; ${ }^{1} \mathrm{H}$ NMR (300 $\left.\mathrm{MHz}, \mathrm{CDCl}_{3}\right) \delta 7.44-6.96(4 \mathrm{H}, \mathrm{m}, \mathrm{Ar}), 5.34(1 \mathrm{H}, \mathrm{s}, 12-\mathrm{H})$ $5.30(1 \mathrm{H}, \mathrm{s}), 5.25(1 \mathrm{H}, \mathrm{d}, J=1.2 \mathrm{~Hz}), 4.50(1 \mathrm{H}, \mathrm{m}, 10-\mathrm{H})$, $2.60(1 \mathrm{H}, \mathrm{m}, 9-\mathrm{H}), 2.28(1 \mathrm{H}, \mathrm{dt}, J=13.8,3.7 \mathrm{~Hz}), 2.01-1.19$ $(12 \mathrm{H}, \mathrm{m}), 1.26\left(3 \mathrm{H}, \mathrm{s}, \mathrm{CH}_{3}\right.$ at C3), $0.96\left(3 \mathrm{H}, \mathrm{d}, J=6.1 \mathrm{~Hz}, \mathrm{CH}_{3}\right)$, $0.92\left(3 \mathrm{H}, \mathrm{d}, J=7.6 \mathrm{~Hz}, \mathrm{CH}_{3}\right) ;{ }^{13} \mathrm{C} \mathrm{NMR}\left(75 \mathrm{MHz}, \mathrm{CDCl}_{3}\right)$ $\delta 145.09,137.56,128.04\left(1 \mathrm{C}, \mathrm{d}, J_{\mathrm{C}-\mathrm{F}}=8.2 \mathrm{~Hz}\right), 115.18,114.90$, 114.40, 102.80 (C12), 89.72 (C10), 81.04, 71.50, 52.13, 44.16, $37.54,36.67,36.12,34.46,30.48,25.74,24.92,24.79,20.07$, 12.65; MS $m / z\left(\mathrm{CI}, \mathrm{NH}_{3}\right) 373.2$ (9\%), 357.2 (100), 343.2 (19), 267.2 (8), 221.2 (9), 162.1 (7); Found 420.25622. $\mathrm{C}_{24} \mathrm{H}_{35} \mathrm{NO}_{4} \mathrm{~F}$ $\left[\mathrm{M}+\mathrm{NH}_{4}\right]^{+}$requires 420.25501 .

\section{0ß-[2-(2-Fluorophenyl)allyl]deoxoartemisinin 11e}

This was synthesised in accordance to general procedure 4 using 10e $(0.46 \mathrm{~g}, 2.2 \mathrm{mmol})$. Purification of the product resulted in a colourless glue $\left(0.14 \mathrm{~g}, 70 \%\right.$ yield). $v_{\max }$ (Nujol mull $) / \mathrm{cm}^{-1}$ 2923.4, 1448.2, 1375.4, 1092.9, 879.7; ${ }^{1} \mathrm{H}$ NMR (300 $\left.\mathrm{MHz}, \mathrm{CDCl}_{3}\right) \delta 7.37-6.98(4 \mathrm{H}, \mathrm{m}, \mathrm{Ar}), 5.40(1 \mathrm{H}, \mathrm{s}), 5.33(1 \mathrm{H}, \mathrm{s}$ 12-H), $5.24(1 \mathrm{H}, \mathrm{s}), 4.40(1 \mathrm{H}, \mathrm{m}, 10-\mathrm{H}), 2.61(1 \mathrm{H}, \mathrm{m}, 9-\mathrm{H}), 2.29$ $(1 \mathrm{H}, \mathrm{dt}, J=12.8,3.9 \mathrm{~Hz}), 2.01-1.17(12 \mathrm{H}, \mathrm{m}), 1.28\left(3 \mathrm{H}, \mathrm{s}, \mathrm{CH}_{3}\right.$ at $\mathrm{C} 3), 0.96\left(3 \mathrm{H}, \mathrm{d}, J=6.0 \mathrm{~Hz}, \mathrm{CH}_{3}\right), 0.88(3 \mathrm{H}, \mathrm{d}, J=7.5 \mathrm{~Hz}$ $\left.\mathrm{CH}_{3}\right) ;{ }^{13} \mathrm{C}$ NMR $\left(75 \mathrm{MHz}, \mathrm{CDCl}_{3}\right) \delta 158.31,143.06,130.83$ $128.81(1 \mathrm{C}, \mathrm{d}, J=8.2 \mathrm{~Hz}), 124.09,117.61,115.56(1 \mathrm{C}, \mathrm{d}$, $J=23.0 \mathrm{~Hz}), 102.88(\mathrm{C} 12), 89.51$ (C10), 81.06, 72.09, 52.23, $44.29,37.53,36.70,34.49,30.37,25.81,24.88,24.79,20.12$, 12.68; MS $m / z$ (EI) 312 (21.94\%), 175 (38.27), 163 (42.18), 162 (44.22), 161 (39.29), 149 (23.30), 147 (20.75), 135 (39.63), 133 (29.08), 123 (40.65), 121 (35.37), 115 (22.62), 109 (78.23), 107 (28.06), 101 (21.09), 95 (43.54), 93 (31.12), 91 (20.58), 81 (39.46), 79 (27.89), 71 (27.72), 69 (40.48), 67 (33.33), 55 (67.35), 43 (100.00), 41 (37.93); Found 402.22001. $\mathrm{C}_{24} \mathrm{H}_{31} \mathrm{FO}_{4}$ requires 402.22064 .

\section{0ß-[2-(4-Trifluoromethylphenyl)allyl]deoxoartemisinin $11 f$}

This was synthesised in accordance to general procedure 4 using $7 \mathbf{a}(0.08 \mathrm{~g}, 0.3 \mathrm{mmol})$. Purification of the product resulted in a white glue $(0.04 \mathrm{~g}, 81 \%$ yield $) . v_{\max }$ (Nujol mull $) / \mathrm{cm}^{-1}$ $2923.5,1456.5,1376.1,1127.4,879.9 ;{ }^{1} \mathrm{H}$ NMR $(300 \mathrm{MHz}$, $\left.\mathrm{CDCl}_{3}\right) \delta 7.59-7.50(4 \mathrm{H}, \mathrm{m}, \mathrm{Ar}), 5.42(1 \mathrm{H}, \mathrm{s}), 5.37(1 \mathrm{H}, \mathrm{s}$ 12-H), $5.33(1 \mathrm{H}, \mathrm{s}), 4.52(1 \mathrm{H}, \mathrm{m}, 10-\mathrm{H}), 2.64(1 \mathrm{H}, \mathrm{m}, 9-\mathrm{H}), 2.31$ $(1 \mathrm{H}, \mathrm{m}), 2.09-1.05(12 \mathrm{H}, \mathrm{m}), 1.21\left(3 \mathrm{H}, \mathrm{s}, \mathrm{CH}_{3}\right.$ at $\left.\mathrm{C} 3\right), 0.96(3 \mathrm{H}$ $\left.\mathrm{d}, J=6.3 \mathrm{~Hz}, \mathrm{CH}_{3}\right), 0.94\left(3 \mathrm{H}, \mathrm{d}, J=7.8 \mathrm{~Hz}, \mathrm{CH}_{3}\right) ;{ }^{13} \mathrm{C} \mathrm{NMR}$ $\left(75 \mathrm{MHz}, \mathrm{CDCl}_{3}\right) \delta 145.12,135.12,126.80,125.26,116.30$, 102.73 (C12), 89.83 (C10), 81.01, 71.19, 52.05, 44.06, 37.54, $36.27,35.96,34.42,30.49,25.61,24.91,24.80,20.03,12.57$; MS $\mathrm{m} / \mathrm{z}(\mathrm{EI}) 225(20.00 \%), 163(37.31), 162$ (66.92), 159 (27.12), 151 (27.31), 124 (23.46), 123 (25.77), 121 (21.92), 109 (27.69), 107 (25.58), 95 (24.62), 81 (37.88), 79 (26.15), 71 (24.62), 69
(38.08), 55 (64.62), 43 (100.00), 41 (35.38); Found 452.21724. $\mathrm{C}_{25} \mathrm{H}_{31} \mathrm{~F}_{3} \mathrm{O}_{4}$ requires 452.21747 .

\section{0ß-[2-(3-Fluorophenyl)allyl]deoxoartemisinin $11 \mathrm{~g}$}

This was synthesised in accordance to general procedure 4 using $7 \mathbf{b}(0.28 \mathrm{~g}, 1.3 \mathrm{mmol})$. Purification of the product resulted in a white glue $(0.14 \mathrm{~g}, 90 \%$ yield $) . v_{\max }$ (Nujol mull $) / \mathrm{cm}^{-1}$ 2956.0, 1462.0, 1377.0, 1124.0, 872.0; ${ }^{1} \mathrm{H}$ NMR $(300 \mathrm{MHz}$, $\left.\mathrm{CDCl}_{3}\right) \delta 7.31-6.92(4 \mathrm{H}, \mathrm{m}, \mathrm{Ar}), 5.38(1 \mathrm{H}, \mathrm{d}, J=1.0 \mathrm{~Hz}), 5.34$ $(1 \mathrm{H}, \mathrm{s}, 12-\mathrm{H}), 5.31(1 \mathrm{H}, \mathrm{d}, J=1.1 \mathrm{~Hz}), 4.52(1 \mathrm{H}, \mathrm{m}, 10-\mathrm{H}), 2.62$ $(1 \mathrm{H}, \mathrm{m}, 9-\mathrm{H}), 2.27(1 \mathrm{H}, \mathrm{dt}, J=13.7,3.8 \mathrm{~Hz}), 2.02-1.18(12 \mathrm{H}$, m), $1.27\left(3 \mathrm{H}, \mathrm{s}, \mathrm{CH}_{3}\right.$ at $\left.\mathrm{C} 3\right), 0.96\left(3 \mathrm{H}, \mathrm{d}, J=7.6 \mathrm{~Hz}, \mathrm{CH}_{3}\right), 0.93$ $\left(3 \mathrm{H}, \mathrm{d}, J=7.7 \mathrm{~Hz}, \mathrm{CH}_{3}\right) ;{ }^{13} \mathrm{C} \mathrm{NMR}\left(75 \mathrm{MHz} \mathrm{CDCl}_{3}\right) \delta 162.95$ $\left(1 \mathrm{C}, \mathrm{d}, J_{\mathrm{C}-\mathrm{F}}=244.1 \mathrm{~Hz}\right), 145.02,143.97\left(1 \mathrm{C}, \mathrm{d}, J_{\mathrm{C}-\mathrm{F}}=7.1 \mathrm{~Hz}\right)$, $129.66\left(1 \mathrm{C}, \mathrm{d}, J_{\mathrm{C}-\mathrm{F}}=8.3 \mathrm{~Hz}\right), 122.10,115.35,114.07(1 \mathrm{C}, \mathrm{d}$, $\left.J_{\mathrm{C}-\mathrm{F}}=21.3 \mathrm{~Hz}\right), 113.45\left(1 \mathrm{C}, \mathrm{d}, J_{\mathrm{C}-\mathrm{F}}=21.8 \mathrm{~Hz}\right), 102.80(\mathrm{C} 12), 89.75$ (C10), 81.03, 71.42, 52.11, 44.13, 37.54, 36.68, 35.88, 34.45, 30.48, 25.71, 24.93, 24.80, 20.06, 12.61; MS m/z (EI) 175 (20.98\%), 165 (26.57), 163 (35.31), 162 (54.55), 161 (21.85), 147 (21.50), 138 (30.42), 135 (21.50), 133 (22.20), 124 (26.75), 123 (22.20), 109 (41.08), 95(21.85), 81 (28.50), 79(22.38), 69(24.83), 67 (22.90), 55 (60.14), 43 (100.00), 41 (37.41); Found 402.22040. $\mathrm{C}_{24} \mathrm{H}_{31} \mathrm{O}_{4} \mathrm{~F}$ requires 402.22064; found: $\mathrm{C}, 71.14$; $\mathrm{H}, 7.71$; requires $\mathrm{C}, 71.62$; $\mathrm{H}, 7.76 \%$.

\section{$\mathrm{FeCl}_{2}$-mediated degradation of $10 \beta$-(2-phenylallyl)deoxo- artemisinin (11a)}

To a solution of $11 \mathrm{a}(0.14 \mathrm{~g}, 0.4 \mathrm{mmol})$ in $\mathrm{CH}_{3} \mathrm{CN}(13 \mathrm{~mL})$ was added $\mathrm{FeCl}_{2} \cdot 4 \mathrm{H}_{2} \mathrm{O}(0.1 \mathrm{~g}, 0.5 \mathrm{mmol})$ under nitrogen atmosphere. The reaction was left stirring at $\mathrm{rt}$ for $30 \mathrm{~min}$ before being filtered through Celite and washed with $\mathrm{CH}_{3} \mathrm{CN}$. Concentration under reduced pressure and flash column chromatography using ethyl acetate and hexane $(1: 10)$ as eluent yielded the product 12 as yellow oil ( $0.86 \mathrm{~g}, 60 \%$ yield). $v_{\max }$ (Nujol mull)/ $\mathrm{cm}^{-1}$ 3042.1, 2926.3, 1713.8, 1628.8; ${ }^{1} \mathrm{H}$ NMR $(300 \mathrm{MHz}$, $\left.\mathrm{CDCl}_{3}\right) \delta 7.99(1 \mathrm{H}, \mathrm{s}, \mathrm{HC}=\mathrm{O}), 7.43-7.21(5 \mathrm{H}, \mathrm{m}, \mathrm{Ar}), 5.35(1 \mathrm{H}$, br s, $\mathrm{C}=\mathrm{CH}), 5.14(2 \mathrm{H}, \mathrm{m}, \mathrm{C}=\mathrm{CH} \& 10-\mathrm{H}), 2.96-1.26(12 \mathrm{H}, \mathrm{m})$, $2.11\left(3 \mathrm{H}, \mathrm{s}, \mathrm{CH}_{3}\right), 1.01(3 \mathrm{H}, \mathrm{d}, J=6.3 \mathrm{~Hz}), 0.99(3 \mathrm{H}, \mathrm{d}, J=$ $\left.6.9 \mathrm{~Hz}, \mathrm{CH}_{3}\right) ;{ }^{13} \mathrm{C} \mathrm{NMR}\left(75 \mathrm{MHz}, \mathrm{CDCl}_{3}\right) \delta 213.31,209.02$, $160.66,144.16,140.12,128.47,127.79,126.33,115.85,72.53$, $57.52,54.42,41.38,38.22,34.60,34.13,31.02,29.81,20.40$, 20.36, 12.26; $\mathrm{MS} \mathrm{m} / \mathrm{z}\left(\mathrm{CI}, \mathrm{NH}_{3}\right) 355.3(13 \%), 339.3$ (100), 221.1 (6); Found 402.26497. $\mathrm{C}_{24} \mathrm{H}_{36} \mathrm{NO}_{4}\left[\mathrm{M}+\mathrm{NH}_{4}\right]^{+}$requires 402.26443 .

\section{References}

1 H. Jomaa, J. Wiesner, S. Sanderbrand, B. Altincicek, C. Weidemeyer, M. Hintz, I. Tübachova, M. Eberl, J. Zeider, H. K. Liechtenthaler, D. Soldati and E. Beck, Science, 1999, 285, 1573 .

2 D. Klayman, Science, 1985, 228, 1049.

3 J. K. Baker, R. H. Yarber, C. D. Hufford, I.-S. Lee, H. N. Elsohly and J. D. McChesney, Biomed. Environ. Mass Spectrom., 1988, 18, 337.

4 A. J. Lin, M. Lee and D. L. Klayman, J. Med. Chem., 1989, 32, 1249. 5 J. L. Maggs, L. P. D. Bishop, G. Edwards, P. M. O'Neill, S. A. Ward, P. A. Winstanley and B. K. Park, Drug Metab. Dispos., 2000, 28, 209.

6 J. M. Grace, A. J. Aguilar, K. M. Trotman and T. G. Brewer, Drug Metab. Dispos., 1998, 26, 313

7 P. M. O'Neill, F. Scheinmann, A. V. Stachulski, J. L. Maggs and B. K. Park, J. Med. Chem., 2001, 44, 1467.

8 M. Jung and S. Lee, Bioorg. Med. Chem. Lett., 1998, 8, 1003.

9 (a) M. Jung, D. A. Bustos, H. N. Elsohly and J. D. McChesney, Synlett, 1990, 743; (b) M. Jung, D. Yu, D. A. Bustos, H. N. Elsohly and J. D. McChesney, Bioorg. Med. Chem. Lett., 1991, 741; (c) M. Jung and S. Lee, Heterocycles, 1997, 45, 1055.

10 Y. M. Pu and H. Ziffer, J. Med. Chem., 1995, 38, 613

11 J. Ma, E. Katz, D. E. Kyle and H. Ziffer, J. Med. Chem., 2000, 43, 4228.

12 S. H. Woo, M. H. Parker, P. Ploypradith, J. Northrop and G. H. Posner, Tetrahedron Lett., 1998, 39, 1533. 
13 H. O'Dowd, P. Ploypradith, S. Xie, T. A. Shapiro and G. H. Posner, Tetrahedron, 1999, 55, 3625.

14 D.-Y. Wang, Y. Wu, Y.-L. Wu, Y. Li and F. Shan, J. Chem. Soc., Perkin Trans. 1, 1999, 1827

15 P. M. O’Neill, N. L. Searle, K.-W. Kan, R. C. Storr, J. L. Maggs, S. A. Ward, K. Raynes and B. K. Park, J. Med. Chem., 1999, 42, 5487.

16 For the first reports of a carbon-centred radical intermediate in iron(II) promoted reductive cleavage of an antimalarial trioxane see (a) G. H. Posner and C. H. Oh, J. Am. Chem. Soc., 1992, 114, 8328; (b) G. H. Posner, D. Wang, J. N. Cumming, C. H. Oh, A. N. French, A. N. Bodley and T. A. Shapiro, J. Med. Chem., 1995, 38, 2273.

17 S. Hindley, S. A. Ward, R. C. Storr, N. L. Searle, P. G. Bray, B. K. Park, J. Davies and P. M. O'Neill, J. Med. Chem., 2001, manuscript in preparation.

18 M. Jung and J. Bae, Heterocycles, 2000, 53, 261.

19 G. H. Posner, S. H. Woo, P. Ploypradith, M. H. Parker, T. A Shapiro, J. S. Elias, J. Northrop, Q. Y. Zheng, N. J. Wayne, C. Murray, R. J. Daughenbaugh, US Pat., 6160004, Dec. 12, 2000.

20 Y. M. Pu, H. Yeh and H. Ziffer, Heterocycles, 1993, 36, 2099.

21 Y. M. Pu, D. S. Torok, H. Ziffer, X. Q. Pan and S. Meshnick, J. Med. Chem., 1995, 38, 4120.

22 T. T. T. Nga, C. Menage, J. P. Begue, D. Bonnet Delpon and J. C. Gantier, J. Med. Chem., 1998, 41, 4101.
23 B. A. Narayanan and W. H. Bunnelle, Tetrahedron Lett., 1987, 28, 6261.

24 T. Hayashi, Y. Katsuro and M. Kumada, Tetrahedron Lett., 1980, 21, 3915 .

25 (a) A. D. Petrov, V. A. Ponomarenko and A. D. Snegova, Dokl. Akad. Nauk SSSR, 1957, 112, 79; (b) I. Flemming and A. Pearce, J. Chem. Soc., Perkin Trans. 1, 1981, 251; (c) M. Ochiai, E. Fujita, M. Arimoto and H. Yamaguchi, J. Chem. Soc., Chem. Commun., 1982, 1108; (d) T. Yamazaki and N. Ishikawa, Chem. Lett., 1984, 521.

26 M. B. Anderson and P. L. Fuchs, Synth. Commun., 1987, 17, 621

27 (a) T. Imamoto, T. Kusumoto, Y. Tawarayama, Y. Sugiura, T. Mita, Y. Hatanaka and M. Yokoyama, J. Org. Chem., 1984, 49, 3904; (b) T. Imamoto, N. Takiyama and K. Nakamura, Tetrahedron Lett., 1985, 26, 4763; (c) S. Fukuzawa, T. Fujinami and S. Sakai, J. Organomet. Chem., 1986, 299, 179.

28 M. D. Lewis, J. K. Cha and Y. Kishi, J. Am. Chem. Soc., 1982, 104, 4976.

29 S. R. Meshnick, T. E. Taylor and S. Kamchongwongpaisan, Microbiol. Rev., 1996, 60, 301.

30 For another recent study with C-10 carba analogues see P. M. O'Neill, N. L. Searle, K.-W. Wan, K.-R. C. Storr, J. L. Maggs, S. A. Ward, K. Raynes and B. K. Park, J. Med. Chem., 1999, 42, 5487.

31 G. H. Posner, J. N. Cumming, S.-H. Woo, P. Ploypradith, S. Xie and T. A. Shapiro, J. Med. Chem., 1998, 41, 940. 